ARTIKEL

DOI: 10.47776/MJPRS.002.01.01

\title{
Pendidikan Anti Korupsi sebagai Tindakan Preventif Perilaku Koruptif
}

\section{Anti-Corruption Education as a Preventive Action for Corrupt Behavior}

\section{Dhevy Setya Wibawa}

Fakultas Psikologi Universitas Katolik Indonesia Atma Jaya

Email: dhevy.wibawa@atmajaya.ac.id

\section{Murniati Agustian}

Fakultas Pendidikan dan Bahasa Universitas Katolik Indonesia Atma Jaya

Email: murniati.agustian@atmajaya.ac.id

\section{Tri Warmiyati}

Fakultas Psikologi Universitas Katolik Indonesia Atma Jaya

Email: maria.triwarmiyati@atmajaya.ac.id

\begin{abstract}
Abstrak
Korupsi merupakan perilaku yang sudah membudaya dan fenomena ini umum dijumpai di masyarakat. Keprihatinan muncul karena pelaku korupsi ditemukan baik di lembaga pemerintah maupun swasta, serta melibatkan pimpinan lembaga yang sejatinya menjadi role model bagi generasi muda. Upaya yang telah ditempuh untuk mengurangi meningkatnya kasus korupsi adalah melalui aspek hukum. Namun upaya preventif melalui aspek pendidikan yang mampu membongkar "budaya korupsi", belum banyak diterapkan. Pendidikan anti korupsi merupakan upaya preventif untuk membangun kesadaran dan integritas diri terhadap perilaku koruptif. Tujuan penelitian untuk memperoleh gambaran apakah pendidikan anti korupsi dapat mengembangkan kepekaan dan kepedulian mahasiswa terhadap masalah korupsi. Metode penelitian berupa penelitian tindakan melalui refleksi diri secara kolektif yang diintegrasikan dengan pendekatan student centered learning yang dilakukan secara berkelompok dan dicapai melalui tindakan kritis reflektif anggota kelompok sebagai individu yang diukur hasil belajarnya. Partisipan penelitian ini adalah 25 mahasiswa, yang berasal
\end{abstract}


dari 7 fakultas. Hasil temuan yang diperoleh yaitu mahasiswa mampu mengidentifikasi tindakan koruptif berdasarkan pengalaman pribadi dan kelompok. Tindakan korupsi yang ditemukan pada mahasiswa misalnya korupsi waktu, datang terlambat, menyontek. Partisipan juga mampu mengidentifikasi dampak perilaku korupsi waktu pada individu maupun lembaga (ormawa). Partisipan menyadari dengan melakukan korupsi waktu akan mengakibatkan 'efek domino' dari tindakan koruptif tersebut. Pada Tahap refleksi, partisipan mengungkapkan adanya nilai-nilai integritas dalam bentuk kejujuran, bertanggungjawab dan konsistensi antara sikap dan perilaku, serta nilai agama yang diimani sebagai benteng menangkal tindakan koruptif. Pelatihan ditindaklanjuti dalam bentuk rencana aksi bagi perubahan diri yang berintegritas dan pengelolaan organisasi mahasiswa yang anti koruptif.

Kata kunci: perilaku anti korupsi, pendidikan anti korupsi, integritas diri, student centered learning

\begin{abstract}
Corruption has already become a part of culture in the society. Corruption happens in both government and private sector; the most concerning thing is the involvement of the head of institutions which supposed to be a role model for young generation. There are a lot of things have been done to decrease our corruption cases from law perspective, unfortunately a preventive attempt from education perspective has not much been applied. Anti-corruption education is a preventive effort to build self-awareness and integrity against corruptive behavior. The research objective was to obtain an overview of whether anti-corruption education could develop students' sensitivity and concern for corruption issues. The research method used is action research through collective self-reflection which is integrated with the student-centered learning approach carried out in groups and is achieved through reflective critical action of group members as individuals whose learning outcomes are measured. There were 25 university students from 7 faculties participated in this research. The findings showed that students were able to identify corrupt actions based on personal and group experiences. Participants were also able to identify the impact of time corrupt behavior on individuals and institutions. In the reflection stage, participants reveal the values of integrity such as honesty, responsibility and consistency between attitudes and behavior, as well as religious values which believed to be a fortress against corrupt actions. The action research is followed up by making an action plan to become a person with an integrity and in managing anticorruption student organizations.
\end{abstract}

Keywords: anti-corruption behavior, anti-corruption education, self-integrity, student centered learning

\title{
Pendahuluan
}

Korupsi merupakan perilaku yang sudah membudaya dan fenomena korupsi umum dijumpai di masyarakat. Kasus korupsi ditemukan dari pemerintah daerah 
hingga pemerintah pusat. Komisi Pemberantasan Korupsi (KPK) pada tahun 2018 telah menangani 93 tindakan pidana korupsi, jumlah paling tinggi, 61 tindakan di tingkat pemerintahan kabupaten/kota, 17 tindakan di tingkat pemerintahan propinsi, 13 tindakan di kementrian/lembaga dan 2 tindakan di DPR/DPRD. Modus korupsi yang mereka gunakan melalui pengadaan barang dan praktik penyuapan yang termasuk gratifikasi. Praktik suap yang sering dianggap sebagai kebiasaan (tradisi) di masyarakat Indonesia yaitu saling memberikan hadiah (Dua, Gunawan, Ristyantoro 2019).

Keprihatinan muncul karena pelaku-pelaku korupsi ditemukan baik di lembaga pemerintah maupun swasta, serta melibatkan pimpinan lembaga yang sejatinya menjadi role model bagi generasi muda. Perilaku korupsi mampu tersebar bagaikan metastatis pada sel kanker yang menyebar dengan dahsyat bisa mengikat sel-sel tubuh lainnya (Adisusanto dkk. 2013). Dengan kata lain korupsi mampu menulari dan mempengaruhi orang maupun sistem dengan tersembunyi menyebar dan berkembang biak tidak terkecuali di kalangan orang muda.

Berbagai upaya telah dilakukan untuk mengurangi meningkatnya kasus korupsi di kalangan mahasiswa, salah satunya dilakukan oleh Widhiyaastuti dan Ariawan (2018) ditemukan bahwa generasi muda menyadari bahwa korupsi di Indonesia sudah sangat kritis dan merupakan perbuatan yang melawan hukum serta merugikan. Namun saat diminta mengembangkan perilaku anti koruptif masih belum siap seperti tidak menyontek dan tidak datang terlambat, tidak menggelapkan uang orangtua.

Hasil temuan penelitian tersebut menjadi penting karena menumbuhkan perilaku anti koruptif sebagai upaya preventif yang mampu membongkar "budaya korupsi" dikalangan generasi muda. Asal kata korupsi dari kata corruptio yang berarti hal merusak, pembusukan, peyuapan, kerusakan, kebusukan. Menurut Priyono (dalam Dua, dkk. 2019) kemerosotan yang menyangkut keutuhan fisik dan integritas moral akibat dari perbuatan seperti menyuap, menipu, memalsukan merusak bentuk. Sejalan dengan pendapat Adnan dari ICW (dalam Harini 2016) dua komponen dalam korupsi yaitu adanya niat dan kesempatan. Untuk mencegah dan berkembangnya niat dan kesempatan korupsi perlu menumbuhkan nilai integritas pribadi.

Sehingga tujuan penelitian untuk memperoleh gambaran apakah pendidikan anti korupsi dapat mengembangkan kepekaan dan kepedulian mahasiswa terhadap masalah korupsi, baik secara pribadi, kelompok maupun kelembagaan.

Korupsi. Korupsi pada prinsipnya merupakan perbuatan yang secara umum dilakukan dengan tujuan untuk memperoleh keuntungan. Dalam upaya memperoleh keuntungan inilah cenderung dipergunakan cara-cara yang kurang baik, misalnya dengan melakukan penyuapan, pemerasan, gratifikasi dan lain (Widhiyaastuti \& Ariawan 2017-2018)

Pendidikan Anti Korupsi. Pendidikan anti korupsi dipandang penting dengan beberapa pendekatan diantaranya pendekatan pengacara, pendekatan bisnis, pendekatan pasar atau ekonomi dan pendekatan budaya. Dalam pendidikan, pendekatan budaya dipandang tepat karena membangun dan memperkuat sikap 
anti korupsi individu melalui pendidikan dengan berbagai cara dan bentuk. Pendekatan ini cenderung membutuhkan waktu yang lama untuk melihat keberhasilannya, namun hasil akan berdampak terlihat dalm jangka panjang (Puspito dkk. 2011).

Mahasiswa sebagai generasi muda merupakan salah satu agen perubahan yang dapat berperan dalam mereduksi korupsi melalui Pendidikan anti korupsi. Menurut Widhiyaastuti \& Ariawan (2017-2018), pendidikan anti koruptif tidak dirancang untuk memberantas korupsi tapi mencegah dengan jalan melatih orang untuk memiliki kesadaran untuk berperilaku anti koruptif. Pendidikan anti koruptif tidak akan memiliki daya guna jika karakter yang terbentuk masih bukan karakter anti koruptif. Pembentukan karakter anti koruptif yang dilakukan melalui pendidikan anti koruptif akan mempertajam dan mengasah idealisme dan integritas yang dimiliki oleh generasi muda dalam memandang korupsi sebagai perbuatan melawan hukum yang harus segera dicegah, ditanggulangi dan diberantas.

Seperti halnya korupsi yang telah membudaya di masyarakat Indonesia, maka untuk membuat perubahan perlu adanya Pendidikan anti korupsi yang dapat secara cepat atau lambat menjadi budaya baru yaitu budaya anti korupsi. Dalam menumbuhkan budaya anti korupsi, yang terpenting adalah tujuan pendidikan nilai. Konsep dasar pendidikan antikorupsi secara filosofis merupakan internalisasi hakikat korupsi (ontologis), pemahaman praktik korupsi (epistemologis) serta aplikasi moral antikorupsi dalam tindakan (aksiologis) untuk mencegah perilaku korupsi (Saifulloh 2017).

Integritas. Kata "integritas" dalam bahasa Inggris integrity yang berarti kuat, kokoh, tidak goyah atau tidak mudah terombangambing. Menurut Robert C, Solomon 1992 (dalam Dua dkk 2019) integritas mencerminkan kepribadian positif yang mestinya dimiliki oleh setiap orang. Salah satu nilai integritas adalah kejujuran, sebaliknya kejujuran bukan mencerminkan integritas. Dalam konteks rahasia negara maka arti kejujuran tidak relevan diterapkan. Maka integritas dapat diartikan sebagai sikap yang kokoh, kuat, dan berani bertindak sesuai dengan nilai-nilai dan keyakinan-keyakinan moral seseorang tentang apa yang kewajiban moral untuk melakukannya.

Enam pokok makna integritas (Dua dkk 2019) pertama, integritas sebagai kemampuan dan kualitas moral yang dimikili oleh individu. Kedua, integritas memampukan individu untuk berani melakukan hal yang baik dan menghindari yang buruk. Ketiga, integritas hipokrasi merupakan tampilan manipulatif dari pribadi yang tidak berintegritas. Keempat, seseorang lebih mudah kehilangan predikat "berintegritas" dan sulit membangun diri predikat "berintegritas"; Kelima, integritas menuntut komitmen dan konsistensi melalui perbuatan; Keenam, membangun integritas moral dan memerangi kemunafikan.

Perlu adanya kesadaran akan perbedaan yang kontras antara korupsi dan integritas adanya perilaku penyelahgunaan kekuasaan dengan memanipulasi kebaikan bersama (common good) akan cenderung mengabaikan tindakan individu yang koruptif yang bisa berdampak destruktif dengan korupsi sistemik (Endro 
2017).

Student Centered Learning. Pembelajaran yang terpusat kepada partisipan didik (student center learning/SCL) dapat dipandang sebagai payung istilah dari beberapa praktik belajar mengajar dimana kegiatan pembelajaran didominasi oleh peserta didik, seperti pembelajaran berbasis proyek, pembelajaran sosial-emosional, pembelajaran kolaboratif dan kooperatif (Nair 2014; Priansa 2017). Pembelajaran yang berpusat pada peserta didik memungkinkan mereka untuk mengarahkan pembelajaran mereka, memaksimalkan pembelajaran mereka, potensi pribadi, dan mengembangkan keterampilan untuk menerapkan pengetahuan untuk memecahkan masalah kehidupan nyata. Melihat karakteristik SCL yang menekankan pembelajaran terpusat kepada peserta didik, terlihat bahwa SCL berakar pada pandangan konstruktivis tentang belajar dan pembelajaran (Hoidn 2017). Konstruktivisme merupakan aliran yang memfokuskan pengembangan kemampuan peserta didik untuk membangun atau mengkonstruksi sendiri pengetahuan baru melalui proses berpikir mensintesis pengetahuan dan pengalaman lama dan baru (Suparman 2014)

Penerapan SCL telah dilakukan pada semua tingkatan dalam pendidikan dengan strategi pembelajaran yang juga beragam, hal ini dapat dipelajari dari hasil beberapa penelitian pada tingkat pendidikan yang berbeda. SCL dengan strategi pembelajaran Active Learning dan Contextual Learning, diterapkan SMP Islam Baitul 'Izzah Nganjuk (Antika 2014). Penelitian Santyasa (2015) mengembangkan 6 (enam) model SCL di SMA, yaitu (1) conceptual change model (CCM), (2) problembased learning (PBL), (3) project-based learning (PjBL), (4) pembelajaran berorientasi nature of science (NOS), (5) pembelajaran kooperatif group investigation (GI), dan (6) self-regulated learning (SRL) dengan hasil SCL efektif untuk meningkatkan penalaran siswa, dan efektif untuk meningkatkan karakter siswa.

Pada prinsipnya SCL dapat digunakan sebagai metode pengajaran setiap mata kuliah di perguruan tinggi. Hasil penelitian di UIN Sunan Kalijaga, menunjukkan bahwa proses pembelajaran mata kuliah metodologi penelitan pada jurusan Sosiologi, mata kuliah filsafat India pada jurusan filsafat agama dan mata kuliah bahasa Arab pada jurusan PBA menggunakan pembelajaran berbasis student centered learning, meskipun dalam penentuan strategi, setiap dosen menggunakan strategi yang berbeda (Kurniawan 2018).

Metode Problem-Based Learning dapat juga dipergunakan untuk menunjang kegiatan SCL di Perguruan Tinggi, karena penggunaan masalah dalam proses pembelajaran dapat menstimulasi keingintahuan mahasiswa sehingga akan mengarahkannya untuk dapat menyelesaikan permasalahan dengan memberikan definisi terhadap masalah serta menetapkan informasi yang telah dikumpulkan atau sedang dicari. Dengan cara ini, mahasiswa akan berusaha mengaitkan informasi yang mereka miliki serta mampu menetapkan topik yang akan mereka pelajari lebih lanjut (Oktarina 2017).

Pada penelitian ini, peneliti menggunakan pendekatan refleksi-aksi-refleksi sebagai strategi pembelajaran dalam SCL. Refleksi adalah cara berpikir tentang apa yang baru dipelajari, atau berpikir ke belakang tentang apa yang sudah dilakukan 
di masa lalu. Refleksi merupakan respon terhadap kejadian, aktivitas atau pengetahuan yang baru diterima (Trianto 2010). Pendekatan refleksi merupakan salah satu penerapan dari teori belajar berdasarkan pengalaman, dengan merujuk pada pernyataan Kolb \& Kolb (2015), digambarkan sebagai sebuah proses yang dinamis dan berulang dengan melibatkan abstraksi pengalaman lewat proses refleksi dan berujung pada aksi atau tindakan konkret.

\section{Metodologi}

Penelitian ini merupakan penelitian tindakan dengan karakteristik adanya refleksi diri secara kolektif yang dilakukan oleh partisipan dalam situasi tertentu untuk meningkatkan rasionalitas pendidikan mereka sendiri, serta pemahaman mereka tentang praktik dan situasi di mana praktik tersebut dilakukan (Gall, Gall \& Borg 2007). Penelitian tindakan ini diintegrasikan dengan pendekatan student central learning (SCL) yang dilakukan secara berkelompok dan dicapai melalui tindakan kritis reflektif anggota kelompok sebagai individu yang diukur hasil belajarnya. Desain penelitian tindakan terlihat dalam Gambar 1.

\section{Gambar 1.}

\section{Desain Penelitian Tindakan}

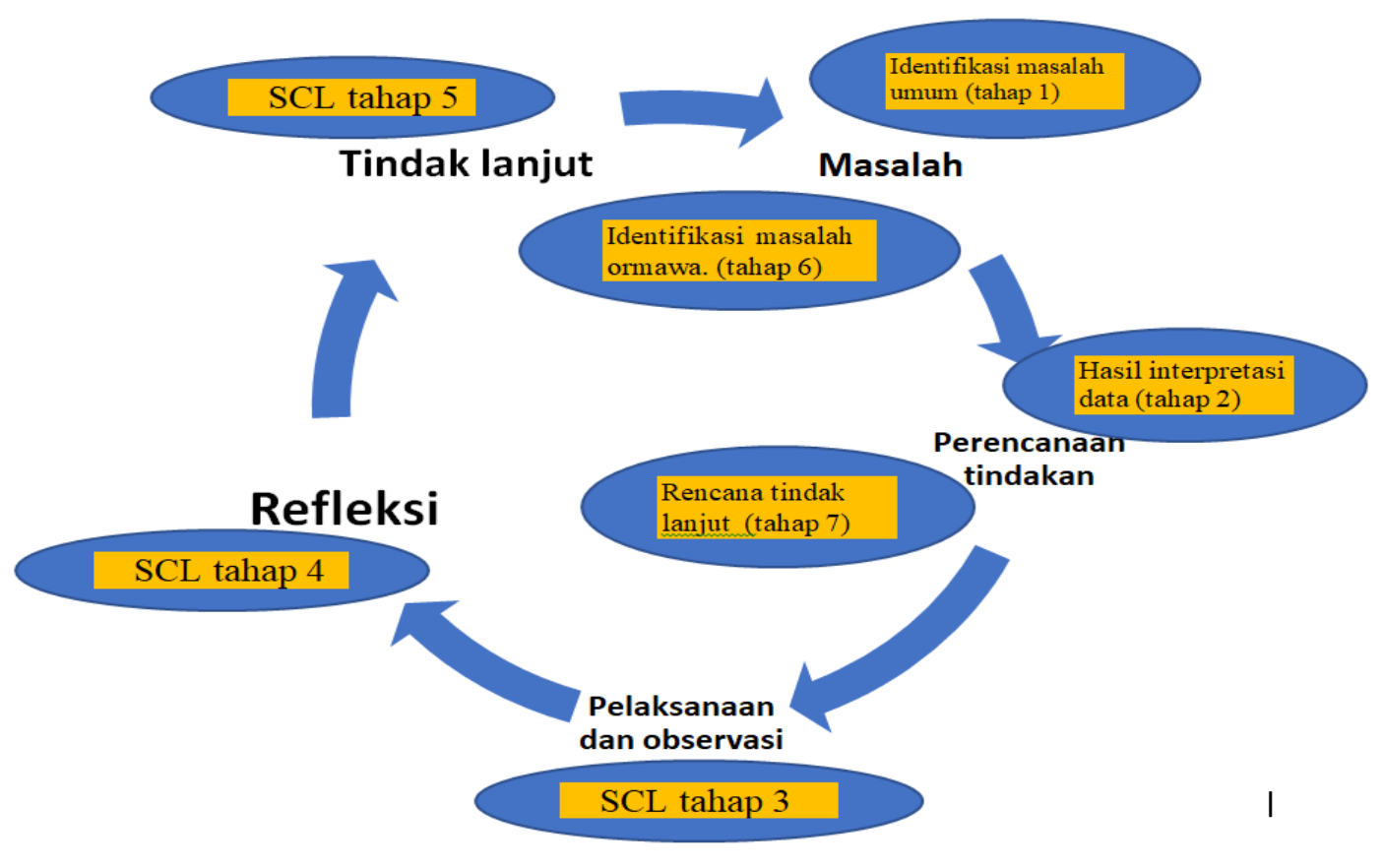

Sumber: Gall, Gall, Borg (2007)

Partisipan yang terlibat dalam penelitian ini 25 mahasiswa, mereka berasal dari 7 fakultas dan 22 organisasi kemahasiswaan. Kegiatan tindakan dilakukan selama 700 menit tatap muka maya, dan belajar secara kolaboratif di luar jam tatap muka maya.

Adapun langkah penelitian Tindakan sebagai berikut:

1. Tahap mengidentifikasi masalah

Pada tahap ini peneliti mengajak partisipan melihat data sekunder kasus 
korupsi di Indonesia. Pengetahuan partisipan digali melalui sharing pengetahuan. Pendekatan yang dilakukan adalah induktif, partisipan menemukan, lalu dikuatkan dengan konsep. Pada tahap ini proses berpikir kritis partisipan sudah diasah.

Hasil tahap ini adalah partisipan mampu 1) menjelaskan pengertian korupsi, 2) mampu mengidentifikasi tindakan korupsi berdasarkan pengalaman di masyarakat dan organisasi.

2. Merencanakan tindakan

Berdasarkan hasil tahap mengidentifikasi masalah, peneliti merancang tindakan. Tindakan dirancang agar partisipan mampu: 1) mengidentifikasi penyebab perilaku koruptif sampai ke akar masalah baik di masyarakat maupun di ormawa. 2) mengidentifikasi dampak perilaku koruptif terhadap individu maupun lembaga (ormawa).

Kegiatan pembelajaran yang dirancang adalah:

- Memilih satu kondisi koruptif (sesuai konteks kelompok mahasiswa) yang perlu dianalisa.

- Mencari apa saja yang menyebabkan kondisi itu muncul, sampai penyebab yang terkecil (akar penyebab) yang biasanya terkait karakter/ sifat manusia hasil ditampilakn dalam web-chart Canva dengan judul "Penyebab".

- Dengan kasus yang sama, mahasiswa diminta menemukan apa saja konsekwensi/dampak logis sampai yang dampak terburuk/fatal yang mungkin terjadi, hasil disajikan dalam web-chart Canva dengan judul "Akibat".

3. Pelaksanaan dan observasi

Tindakan yang direncanakan, dilaksanakan secara daring. Partisipan berdiskusi berdasarkan kelompok yang sudah ditentukan, peneliti mengamati proses diskusi. Proses diskusi tidak selesai pada tatap muka daring, partisipan mengerjakan dengan kolaboratif dan diharapkan menghasilkan bahan prsesentasi dalam bentuk Kanva sebab akibat.

4. Refleksi

Hasil refleksi berupa data kualitatif merupakan alat ukur untuk melihat kepekaan dan kepedulian partisipan untuk melihat sebab akibat. Kembali pada tahap ini proses berpikir partisipan diasah.

5. Tindak lanjut

Hasil refleksi ditindaklanjuti dengan penggalian yang lebih dalam. Partisipan diminta untuk menganalisis data UKM.

Pada tahap ini partisipan diharapkan mampu : 1) mengamati dan berpikir kritis tentang tindakan potensial koruptif pada ormawa, 2) mempresentasikan hasil kerja kelompok.

6. Kembali ke siklus masalah

Hasil tindak lanjut, partisipan mampu berpikir kritis dan melakukan refleksi 
tentang perilaku potensial koruptif mahasiswa dan/ atau pengurus organisasi mahasiswa (ormawa) yang dikaitkan dengan aspek mental, moral, kultural, legal, dan spiritual.

7. Rencana tindak lanjut

Pada tahap ini partisipan diharapkan mampu membuat rencana tinjak lanjut baik untuk organisasi maupun untuk diri sendiri.

Siklus penelitian tindakan berhenti ketika peneliti mengukur hasil rencana tindak lanjut yang dibuat partisipan secara kelompok maupun secara individu. Rencana tindak lanjut merupan rencana preventif yang akan dilaknsakan baik secara kelompok maupun individu.

Jumlah partisipan dalam penelitian yaitu 25 partisipan dengan karakteristik yaitu mahasiswa Unika Atma Jaya, partisipan pelatihan anti korupsi, dan pengurus organisasi mahasiswa.

\section{Temuan dan Analisis}

Karakteristik partisipan dalam pengumpulan data kualitatif adalah mahasiswa Unika Atma Jaya yang berasal dari berbagai fakultas dan program studi. Mereka terpilih menjadi peserta pelatihan dan partisipan dalam penelitian ini karena mewakili unit kegiatan mahasiswa (UKM).

\section{Gambar 2}

\section{Latar Belakang Fakultas Partisipan Penelitian}

Fakultas

25 tanggapan

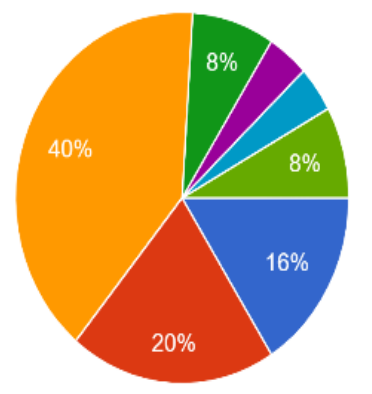

Gambar di atas memperlihatkan latar belakang partisipan berdasarkan asal fakultas. Dari 25 partisipan, 40\% berasal dari Fakultas Ekonomi dan Bisnis (FEB), 20\% dari Fakultas Psikologi (FP), $16 \%$ dari Fakultas Pendidikan dan Bahasa (FPB), 8\% dari Fakultas Hukum (FH), 8 \% dari Fakultas Ilmu Administrasi dan Bisnis (FIABIKOM), 4 \% dari Fakultas Teknobiologi (FTB) dan $4 \%$ dari Fakultas Teknik (FT).

Partisipan dalam penelitian berasal dari 23 unit kegiatan mahasiswa deengan rincian diwakili oleh seorang partisipan untuk Atma Jaya Debating Club, Economic Computer Club, HMPS PBI, PPAL WANACHALA, Pastoran Atma Jaya, UKM Bulu Tangkis, Pat Djiu Wushu, LKMM, ABLS FH, FODIM, UKM Renang Selam, OASE, 
Unit Penelitian Mahasiswa (UPM), Baseball Softball Atma Jaya, Paduan Suara Gita Swara Jaya (PSGSJ), Tim Peduli AIDS, BPM FPB, Humilty, Senat Mahasiswa FT, PENA FPUAJ, 2 partisipan dari MAPLE FPUAJ dan 3 partisipan dari HiMEP.

Tahap Identifikasi Masalah. Dalam tahapan ini, partisipan mampu menjelaskan pengertian korupsi. Selain itu partisipan mampu mengidentifikasi tindakan korupsi berdasarkan pengalaman di masyarakat dan organisasi. Sejumlah tindak korupsi yang diperoleh dari partisipan antara lain korupsi waktu, gratifikasi, menaikkan harga pembelian, menyogok, pelicin, upeti, komisi, dan lain-lain. Partisipan mampu menemukan perilaku korupsi, baik yang dijumpai di masyarakat, dalam pengalaman berorganisasi atau pengalaman sebagai mahasiswa. Tindak korupsi sebagai mahasiswa yang dinyatakan oleh partisipan antara lain, datang terlambat, menyontek, memberi tips, dan memberikan hadiah (gratifikasi) kepada dosen. Beberapa perilaku baru disadari oleh partisipan sebagai tindak koruptif. Ini menunjukkan bahwa ada sejumlah tindak koruptif yang selama ini dianggap lumrah atau wajar dilakukan dalam kehidupan sehari-hari.

Pelatihan anti korupsi yang diberikan kepada mahasiswa memberikan pengetahuan tentang korupsi, batasan dan perilaku serta faktor yang menyebabkan dan akibat dari korupsi. Beberapa partisipan mengungkapkan dengan informasi tersebut mereka menjadi paham tentang arti korupsi.

Metode SCL yang diterapkan dalam pelatihan membantu partisipan memahami tentang korupsi dan penerapan perilaku yang bisa dikategorikan tindak koruptif. Beberapa partisipan baru menyadari bahwa perilaku korupsi itu sendiri tidak selalu diartikan berhubungan langsung dengan uang. Banyak hal yang masuk kategori non-materril dapat dianggap sebagai pemicu perilaku korupsi. Mulai dari perilaku datang terlambat, memberi tips, dll. Dari sesi tahapan pertama partisipan mengetahui informasi tentang tindak korupsi serta aspek yang masuk dalam kategori korupsi, antara lain suap, pemerasan, gratifikasi, penggunaan uang organisasi, menaikkan jumlah pembelian barang.

Perencanaan dan Pelaksanaan Tindakan. Pada tahap ini partisipan pelatihan dibagi dalam kelompok. Setiap kelompok menentukan satu tindak korupsi. Beberapa topik yang dipilih kelompok yaitu korupsi waktu, gratifikasi dosen dan penggunaan uang organisasi. Dengan metode SCL, partisipan secara berkelompok mengidentifikasi penyebab perilaku koruptif sampai ke akar masalah.

Korupsi Waktu. Korupsi waktu dipilih oleh beberapa kelompok sebagai topik diskusi. Dalam Gambar 3 di halaman berikut, dapat teridentifikasi beberapa faktor penyebab terjadinya korupsi waktu, antara lain sikap menyepelekan waktu, telat bangun, tidak menepati janji, tidak peduli, tidak dapat atur waktu, adanya kegiatan lain, malas, egois, dan tidak punya tanggung jawab.

Sementara Gambar 4 menunjukkan hasil identifikasi dampak perilaku korupsi waktu terhadap mahasiswa dan ormawa. Akibat melakukan korupsi waktu maka seseorang datang terlambat, dengan demikian persiapan acara menjadi terlambat, bahkan keterlambatan bisa terjadi saat pengumpulan laporan pertanggungjawaban (LPJ) dan proposal, pengumpulan laporan bisa melewati deadline (tenggat waktu yang telah ditetapkan). Beberapa data juga menggambarkan 'efek domino' dari 
beberapa akibat yang telah disebutkan, antara lain hasil kerja tidak maksimal, mendapat teguran, tidak mendapat kepercayaan dan kegiatan berikutnya bisa terhambat.
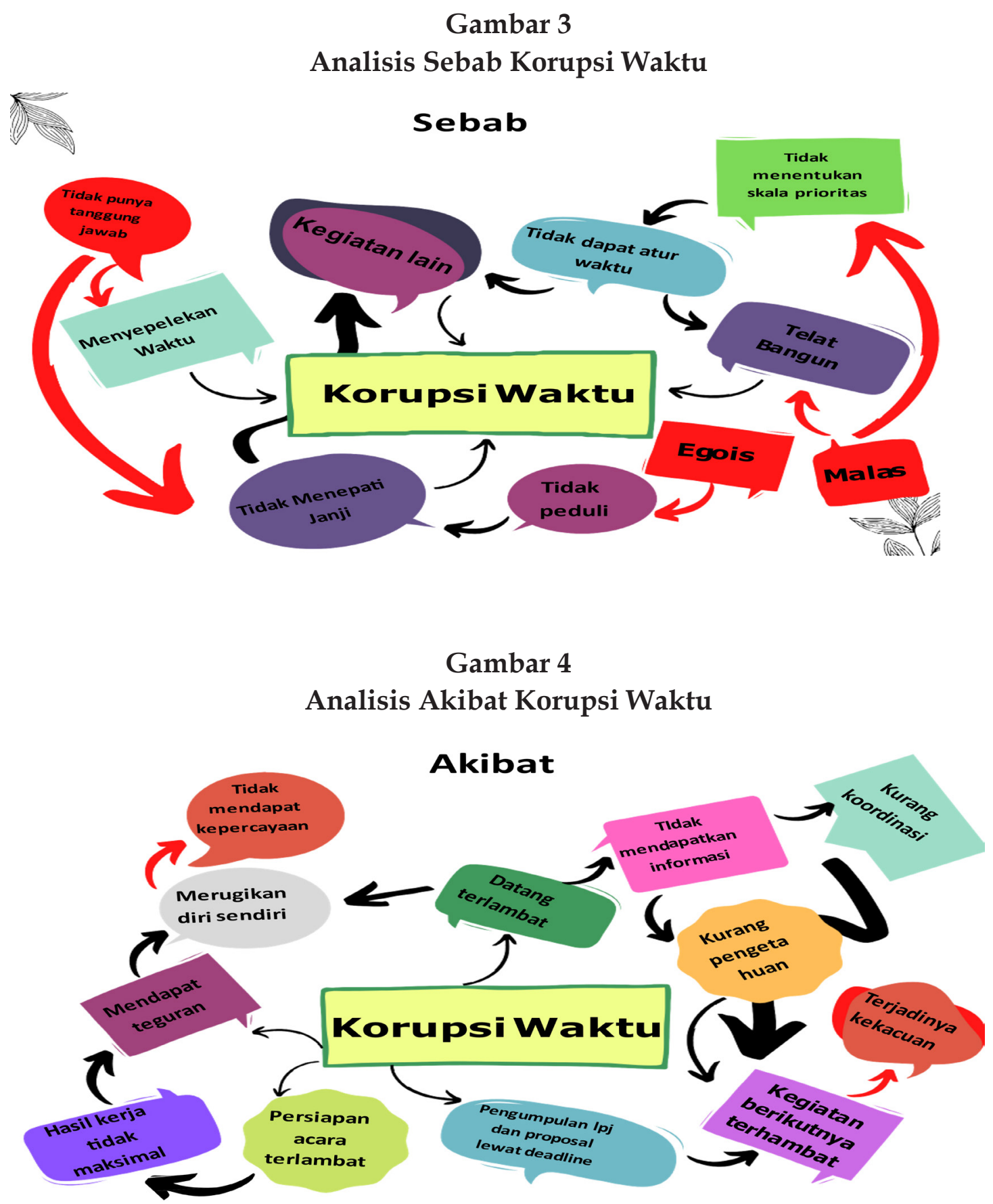

Refleksi. Setelah melalui beberapa tahapan dalam pelatihan maka diharapkan para partisipan telah melalui proses penyadaran tentang tindak korupsi atau perilaku koruptif serta mampu merefleksikan dan memposisikan diri atas isu tindak korupsi. Berdasarkan data yang diperoleh maka korupsi waktu merupakan tindakan yang dilakukan dan diakui oleh mayoritas partisipan. Selain itu, terdapat beberapa kebiasaan yang dilakukan partisipan yang mereka refleksikan sebagai perilaku koruptif, antara lain kebiasaan titip absen, plagiasi atau mengerjakan lain hal saat kuliah dan tidak mendengarkan penjelasan dosen. Korupsi waktu 
merupakan tindakan yang disadari terkait dengan sikap disiplin.

"Saya menyadari bahwa tindakan koruptif yang saya kadang-kadang masih lakukan adalah titip absen kelas, copy-paste pekerjaan orang lain dan telat hadir rapat/acara"

Pembelajaran Jarak Jauh (PJJ) yang saat ini sedang berlangsung membuat mahasiwa lebih leluasa saat mengikuti kuliah secara daring. Namun demikian kontrol saat proses belajar dalam pembelajaran secara daring terbatas sehingga sangat bergantung pada kesadaran dan rasa tanggung jawab masing-masing mahasiwa. Diakui oleh seorang partisipan pada saaat PJJ bisa terjadi sikap tidak disiplin sehingga tidak maksimal dalam mengikuti perkuliahan.

"Dalam keadaan online ini memungkinkan mahasiswa untuk melaksanakan tindakan tidak disiplin seperti saat kelas tidak mendengarkan, telat datang, mengerjakan hal lain saat kelas berlangsung."

Korupsi apapun bentuknya direfleksikan oleh beberapa partisipan berhubungan dengan nilai kejujuran, bertanggungjawab, dan menghargai orang lain. Dengan bersikap jujur, bertanggungjawab, dan menghargai orang lain maka dapat membantu seseorang terhindar dari perilaku koruptif. Partisipan menyadari bahwa korupsi dapat merugikan kepentingan masyarakat. Ketika seseorang menyadari pentingnya menghargai orang lain maka akan menyikapi ketidakdisiplinan yang dilakukannya dapat merugikan teman, komunitas atau organisasi dengan siapa ia berinteraksi dan berkegiatan.

"Mampu bersikap jujur dan bertanggung jawab dalam setiap keputusan yang diambil".

"Menurut saya dimulai dari menetapkan nilai nilai pada pribadi diri sendiri, seperti nilai jujur, menghargai orang lain, dapat mendengerkan pendapat orang lain, dan sabar baik dilingkungan kampus maupun lingkup organisasi"

Sikap jujur disadari oleh seorang partisipan tidak hanya untuk kepentingan diri sendiri tetapi juga untuk kepentingan orang banyak dalam lingkup UKM.

"Memungkinkan bagi seorang bendahara melakukan tindak korupsi, namun dengan jujur pada diri sendiri akan berpengaruh baik tidak hanya bagi pengembangan diri namun juga untuk keberlangsungan UKM serta kenyamanan anggota UKM".

Sikap jujur direfleksikan seorang partisipan berkaitan dengan pengembangan integritas diri, oleh karenanya disadari partisipan untuk menghindar dari perilaku berbohong, ingkar janji dan berusaha untuk bersikap konsisten antara kata dan perbuatan.

“Untuk membangun sikap yang jujur, pertama saya merasa harus berbicara dengan jujur atau sesuai kenyataan. Untuk membangun integritas saya pribadi sebagai mahasiswa, saya harus menghindari berbohong, tidak mengingkari janji, dan tidak mengkhianati kepercayaan yang diberikan. Dari sini saya dapat lebih konsisten dalam perkataan sehingga perbuatan saya juga jujur".

Pengembangan integritas yang dimiliki seseorang menurut seorang partisipan tidak terlepas dari keimanannya pada Tuhan saja. Akan tetapi partisipan mengaitkan dengan pemahaman bahwa korupsi merupakan tindakan yang salah. 
"Pertama-tama saya mulai mulai menambah ketaatan iman saya, karena integritas saya terletak pada iman saya pada Tuhan. setelah itu, saya mulai memberikan sugesti pada diri saya sendiri bahwa korupsi adalah tindakan yang salah. Sebagai tambahan saya juga akan mengadakan dan mengikuti acara - acara yang bertemakan antikorupsi sebagai pengingat diri untuk selalu ingat apa prinsip yang saya pegang"

Partisipan menemukan beberapa sikap yang dalam konteks korupsi dapat diinterpretasikan sebagai tindak koruptif. Mereka mampu memaknai dan juga menyadari dampak negatif yang akan merugikan diri sendiri. Berikut ungkapan partisipan terkait perilaku mahasiswa yang tidak fokus mengikuti kuliah secara daring.

"Saya menyadari dengan melakukan hal tersebut juga merugikan diri saya sendiri karena saya jadi tidak dapat menangkap esensi dari suatu aktivitas sebanyak 100\%".

Rencana Tindak Lanjut. Setelah partisipan melakukan refleksi dan kembali mencermati data-data UKM masing-masing, partisipan menyusun rencana tindak lanjut. Ada dua rencana tindak lanjut yaitu rencana tindak lanjut yang akan diterapkan di organisasi mahasiswa dan rencana tindak lanjut bagi masing-masing partisipan. Berikut adalah ungkapan partisipan tentang rencana tindak lanjut pribadi. Rencana tindak lanjut yang paling sering diungkapkan oleh partisipan yaiatu tentang disiplin diri dan waktu.

"Sebagai mahasiswa yang akan saya lakukan adalah meningkatkan disiplin diri".

"Saya akan berhenti untuk mengulur waktu ketika sedang menjalankan tugas dan job desk yang diberikan walaupun masih jauh dari deadline, sebisa mungkin saya akan memanfaatkan waktu saya semaksimal mungkin dalam sehari hari".

"Saya akan berhenti mencuri-curi waktu untuk melakukan kegiatan lain. Memiliki komitmen dan konsistensi untuk merubah diri menjadi lebih baik lagi".

Rencana Tindak Lanjut Ormawa. Berikut adalah data tentang rencana tindak lanjut yang diungkapkan partisipan sebagai rencana tindak lanjut organisasi mahasiswa. Rencana tindak lanjut berhubungan dengan pembenahan cara mengelola atau manajemen organisasi mahasiswa agar mereka meminimalisir terjadinya perilaku koruptif, antara lain dengan membangun niat dari diri sendiri maupun yang diwujudkan dalam bentuk seperti edukasi dan peraturan. Berikut adalah kutipan yang diungkapkan partisipan dalam rangka membangun niat pribadi.

"Sebagai bendahara, saya ingin mengurus keuangan senat mahasiswa dengan jujur".

"Harus sadar bahwa kebiasaan buruknya merugikan orang banyak".

“Meningkatkan kesadaran pentingnya bersikap jujur dan menanamkan sikap integritas pada setiap anggota/pengurus".

"Menjadi pribadi yang lebih menghargai waktu, bertukar pikiran dengan BPH agar semua BPH dapat menjadi contoh untuk pengurus-pengurus lainnya dan kemudian semua pengurus dapat menjadi contoh untuk semua anggota UKM, dan budaya menghargai waktu pun dapat tercipta di dalam UKM". 
Beberapa rencana tindak lanjut yang bisa memberikan perubahan secara sistemik dalam komunitas atau organisasi, antara lain dengan melakukan kegiatan yang bersifat edukasi seperti sosialisasi, pelatihan. Selain itu beberapa kegiatan sistemik lainnya yaitu membuat berbagai peraturan yang diikuti dengan kegiatan monitoring dan evaluasi. Berikut beberapa rencana tindak lanjut partisipan dalam bentuk peraturan.

"Korupsi waktu atas kemunduran deadline Proposal dan LPJ, telah diatasi dengan pembuatan SOP (prosedur dan ketentuan) Proposal LPJ"

“Membentuk peraturan mengenai denda bagi anggota/pengurus yang telat atau izin tidak mengikuti rapat apabila tidak memberikan alasan yang jelas kepada penyelenggara rapat"

"Membuat kebijakan agar semua bendahara memberikan laporan keuangan dengan rinci".

Adapula rencana tindak lanjut dalam bentuk edukasi / sosialisasi dan penyadaran bagi anggota organisasi.

"Melakukan sosialisasi atau pelatihan kecil kepada seluruh anggota panitia tentang pentingnya bertindak jujur dan bahayanya melakukan korupsi. Jika masih ada anggota organisasi yang melakukan korupsi ini, maka anggota tersebut akan diberikan semacam peringatan".

"Mengadakan pelatihan pendidikan moral dan karakter terutama dalam hal Korupsi".

Beberapa contoh kegiatan monitoring dan evaluasi yang akan dilakukan agar organisasi berjalan dengan baik, sebagai berikut:

"Pengurus atau penanggung jawab juga ada baiknya mengawasi agar setiap orang dapat menyelesaikan tugasnya secepatnya dan tepat waktu".

"Selain itu diadakan pendamping dan follow up secara berkala kepada BPH kepanitiaan. Hal ini juga dirasa sudah efektif karena untuk program kegiatan periode tahun ini sangat minim koruptif".

"Peran supervisi harus dimaksimalkan dengan terus mengontrol. Keuangan, laporan keuangan yaitu kas besar, kas kecil, dan buku pembantu, dapat dilihat oleh seluruh pengurus untuk transparansi".

"Double check setiap dana yang keluar dan masuk dalam rekening UKM, double check LPJ yang dibuat berdasarkan acara".

\section{Diskusi}

Dalam pelatihan dengan menggunakan metode Student Centered Learning, terdapat tiga domain sebagai bagian dari proses pendidikan yaitu pengetahuan, afeksi dan psikomotorik (sikap dan perilaku). Pembahasan pengetahuan korupsi yang kemudian dilanjutkan dengan tahap afeksi melalui proses identifikasi dan analisis kasus korupsi membantu partisipan untuk menemukan sendiri pembelajaraan yang diperoleh dari topik yang sedang dipelajari. Proses menemukan faktor penyebab dan akibat yang terjadi dari satu tindak korupsi ini, 
merupakan proses pembelajaran yang berakar dari pendekatan konstruktivistis dimana partisipan akan menemukan sendiri makna tentang korupsi sebagai hal yang tidak baik dan mengelaborasi melalui proses diskusi antar partisipan. Proses diskusi yang elaboratif membantu partisipan untuk mempertajam analisis dan refleksi "koridor" dari tindak korupsi dan sampai sejauh mana arti keterlibatan seseorang dan lingkungan sekitarnya atas terjadinya tindak koruptif.

Proses belajar yang terpusat pada partisipan pelatihan akan membantu partisipan untuk kemudian memahami, memaknai, menyadari dan mengambil sikap atas pengetahuan tentang tindak korupsi melalui contoh kasus yang sudah dikaji dengan metode analisis sebab dan akibat baik dalam sesi diskusi kelompok maupun pada sesi pleno. Kajian tindak korupsi yang membawa implikasi social di masyarakat membangun kesadaran akan dampak social yang akan terjadi ketika tindak korupsi menjadi "budaya”. Proses yang berawal dari kajian pengetahuan yang kemudian berkembang pada kajian nilai atas perilaku tersebut menyentuh aspek afeksi partisipan. Dinamika tersebut pada akhirnya mampu membawa partisipan untuk memposisikan diri, dengan membangun sikap anti korupsi dan mewujudkannya dalam rencana tindak lanjut baik bagi diri sendiri maupun dalam ranah organisasi kemahasiswaan

Melalui Pendidikan anti korupsi dengan metode Student Centered Learning, maka proses yang natural dan konstruktivis akan berperan dalam pembentukan integritas diri sebagai sikap dasar dari perilaku anti korupsi. Namun demikian masih dijumpai keterbatasan dalam pendidikan anti korupsi karena baru dilakukan pada tataran mahasiswa sebagai pengurus ormawa dengan jumlah terbatas. Apabila pendidikan anti korupsi diberikan secara sistemik maka proses sosialisasi dan terbentuknya budaya anti korupsi pada mahasiswa akan lebih mudah terbentuk.

\section{Pendidikan Anti Korupsi : Konstruksi Nilai Baru}

Pendidikan merupakan salah satu agen sosialisasi yang berperan dalam penanaman nilai anti korupsi yang kemudian terwujud dalam sikap dan perilaku seseorang. Usaha untuk melakukan konstruksi atas nilai anti korupsi, salah satunya tepat dilakukan melalui pendidikan dalam bentuk pelatihan. Proses penyadaran melalui berbagai aktivitas dalam pelatihan anti korupsi akan membentuk nilai baru yaitu anti korupsi dan terinternalisasi pada setiap partisipan pelatihan. Oleh karena itu, Pendidikan anti korupsi nampaknya perlu secara struktural direalisasi dan menjadi salah satu syarat yang perlu dialami oleh mahasiswa di perguruan tinggi atau siswa di sekolah menengah atas sehingga gerakan preventif ini dapat membentuk sikap anti korupsi pada kaum muda. Pelatihan anti korupsi sebagai kegiatan preventif bisa pula dilakukan bagi masyarakat melalui Lembaga atau komunitas. Proses ini akan memperkuat penanaman nilai anti korupsi sebagai salah satu nilai di masyarakat.

Proses penanaman nilai anti korupsi merupakan tindak preventif dalam proses sosialisasi. Meminjam pemikiran Bronfenbrenner tentang peran bioecologis dalam perkembangan manusia (Bronfenbrenner 2005) maka usaha penanaman 
nilai anti korupsi secara efektif sebaiknya melibatkan tataran dari sistem mikro, sistem messo hingga sistem makro. Tindakan preventif dalam bentuk pendidikan anti korupsi perlu berkesinambungan dan disosialisasikan pada lembaga lain, seperti lembaga keluarga, sekolah, lembaga agama, dan media massa.

\section{Penutup}

Pendidikan anti korupsi merupakan tindakan preventif yang dapat membantu terciptanya budaya anti korupsi. Dengan menggunakan metode Student Centered Learning upaya untuk membangun dan meningkatkan kesadaran hukum dan penanaman nilai yang membentuk integritas diri mahasiswa akan menumbuhkan budaya anti korupsi pada mahasiswa sebagai generasi muda yang pada saatnya akan menjadi aktor dalam pembangunan di masyarakat.

Dengan metode Student Centered Learning dimana proses aksi dan refleksi terjadi, akan menumbuhkan kesadaran dan membentuk sikap dan perilaku anti korupsi pada generasi muda. 


\section{Daftar Pustaka}

Integritas. Kamus Besar Bahasa Indonesia (KBBI). Kamus versi daring. Diakses 30 Maret 2021 (https://kbbi.web.id/integritas)

Adisusanto dkk. 2013. Modul Kepemimpinan Berintegritas. Jakarta: Yayasan Bhumiksara

Antika, Reza Rindy. 2014. "Proses Pembelajaran Berbasis Student Centered Learning (Studi Deskriptif di Sekolah Menengah Pertama Islam Baitul ‘Izzah, Nganjuk)". BioKultur. 3 (1): 251-263. (http://journal.unair.ac.id/downloadfullpapers-bk21a95d451ffull.pdf)

Bronfenbrenner, Urie. 2005. Making Human Beings Human: Bioecological Perspectives on Human Development (Introduction). Thousand Oaks: Sage Publications Inc.

Dua, M, Ujan, A.A., Gunawan, T.S., Ristyantoro, R. 2019. Etika Antikorupsi: Menjadi Professional Berintegritas. Jakarta: Direktorat Pendidikan dan Pelayanan Masyarakat KPK.

Endro, Gunardi. 2017. "Menyelisik Makna Integritas dan Pertentangannya dengan Korupsi". Jurnal-INTEGRITAS. 3 (1): 131-152. (https://jurnal.kpk.go.id/ index.php/integritas/article/view/159/41).

Gall, Meredith D., Gall, Joyce p., Borg, Walter R. 2007. Educationnal Research an Introduction. Boston New York Hongkong: Pearson Allyn And Bacon.

Harini. 2016. ICW dan EHEM (Niat dan Kesempatan untuk Korupsi Harus Dicegah Sedini Mungkin). Diakses 27 Maret 2021 (http://sesawi.xyz/2016/11/03/ icw-dan-ehem-niat-dan-kesempatan-untuk-korupsi-harus-dicegah-sedinimungkin-dimulai-dari-membangun-integritas-diri/\#).

Hoidn, Sabine. 2017. Student-Centered Learning Environments in Higher Education Classrooms. New York: Palgrave Macmillan.

Kurniawan, M. Arif., Miftahillah, Agus., Nasihah, Nilna Milhatan. 2018. "Pembelajaran Berbasis Student-Centered Learning Di Perguruan Tinggi: Suatu Tinjauan di UIN Sunan Kalijaga Yogyakarta". Lentera Pendidikan. 21 (1): 1-11. (http://journal.uin-alauddin.ac.id/index.php/lentera pendidikan/ article/view/1-11).

Kolb, D.A. 2015. Experiential Learning: Experience as the Source of Learning and Development 2nd Edition. Pearson Education Inc.

Nair, Prakash. 2014. Blueprint for Tomorrow: Redesigning Schools for Student-Centered Leaming. Cambridge, Massachusetts: Harvard Education Press.

Oktarina, Putu Santi. 2017. "Implementasi Metode Problem-Based Learning (PBL) Untuk Optimalisasi Student-Centered Learning (SCL) Di Perguruan Tinggi". Jurnal Penjaminan Mutu. 3 (1): 76-86. (https://ejournal.ihdn.ac.id/index. $\mathrm{php} / \mathrm{IPM} /$ article/view/94).

Priansa, Donni Juni. 2017. Pengembangan Strategi \& Model Pembelajaran. Bandung: Pustaka Setia. 
Santyasa, I Wayan., Warphala, I Wayan Sukra., Tegeh, I Made. 2015. “Validasi dan Implementasi Model-Model Student Centered Learning Untuk Meningkatkan Penalaran dan Karakter Siswa Sekolah Menengah Atas". Jurnal Pendidikan Indonesia. 4 (1, April): 512-527. (https://ejournal.undiksha.ac.id/index.php/ IPI/article/view/4890).

Suparman, Atwi. 2014. Desain Instruksional Modern:panduang Para Pengajar dan Inovator Pendidikan. Jakarta: Erlangga.

Saifulloh, Putra Perdana Ahmad. 2017. "Peran Perguruan Tinggi Dalam Menumbuhkan Budaya Anti Korupsi Di Indonesia". Jurnal Hukum $\mathcal{E}$ Pembangunan. 47 (4): 459-476. (http://jhp.ui.ac.id/index.php/home/article/ view/1591).

Trianto. 2010. Mendesain Model Pembelajaran Inovatif-Progresif. Jakarta: Kencana.

Tudge, J. R. H., Mokrova, I., Hatfield, B. E. \& Karnik, R. B. 2009. “Uses and Misuses of Bronfenbrenner's Bioecological Theory of Human Development." Journal of Family Theory \& Review. 1(4): 198-210. (https://onlinelibrary.wiley.com/ doi/abs/10.1111/j.1756-2589.2009.00026.x).

Widhiyaastuti, I.G.A.A.D., Ariawan, I.G.K. 2018. “Meningkatkan Kesadaran Generagi Muda untuk Berperilaku Anti Koruptif Melalui Pendidikan Anti Korupsi". Jurnal Ilmiah Prodi Magister Kenotariatan Acta Comitas. 3(1): 17 - 25. (https://ojs.unud.ac.id/index.php/ActaComitas/article/view/39325). 
18 | Pendidikan Anti Korupsi sebagai Tindakan Preventif Perilaku Koruptif

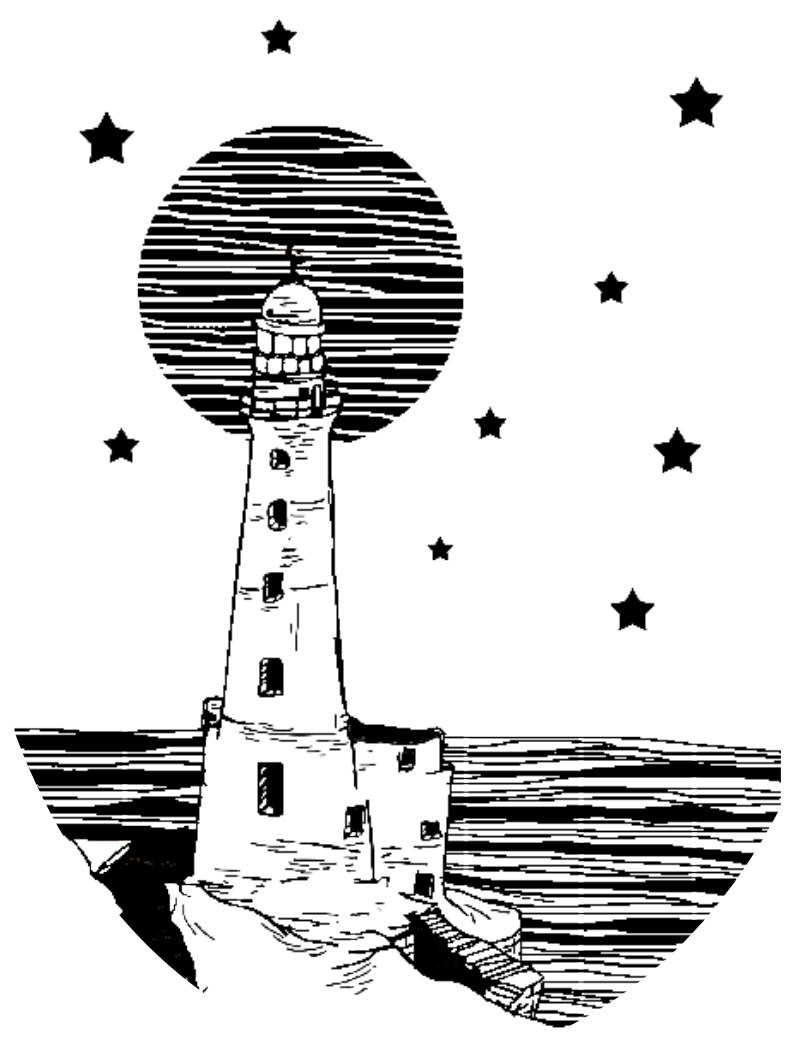

